\title{
The Concept of Tabarruj in the Qur'an according to Muslim Commentators
}

\author{
${ }^{1}$ Mirna Wati, ${ }^{2}$ Hasep Saputra \\ Institut Agama Islam Negeri (IAIN) Curup \\ ${ }^{1}$ mirnawati@gmail.com \\ 2hasepsaputra01@gmail.com
}

\begin{abstract}
Today there are still many Muslimah dressed not in accordance with the rules in the Islamic religion. Good dress habits must be planted early so that the Muslimah get used to and make Islamic dress codes entrenched in society. Tabarruj is a woman's style of dress or attitude that is excessive in order to attract the attention of others when she comes out of her house, deliberately showing the beauty of her face and body and waving her way so that she can see the jewelry in front of other people. the Aim of this research is to know the understanding of paragraph about tabarruj in the Qur'an, inside about rule dressed up or be decorated for woman. In this study the researcher used library research with the method of maudhu'i of interpretation which collects verses of the Quran based on the topic or theme set by all the verses collected based on the period of decline, then studied in depth and thoroughly from various aspects that can be explored, then pay attention to these verses with explanations and relationships with other verses. The Results show that tabarruj in the Qur'an is style dressed up or attitudes woman on purpose interesting other people's attention when she go out from her house and show her beauty.
\end{abstract}

Keyword: Islam, tabarruj, muslim women

\section{Introduction}

The origin word of tabarruj is taken from the word buruj which means "a sky-building that rises high and occupies the height of its

AJIS: Academic Journal of Islamic Studies vol. 3, no. 2, December 2018 IAIN Curup - Bengkulu | p-ISSN 2580-3174, e-ISSN 2580-3190 Available online: http://journal.staincurup.ac.id/index.php/AJIS 
place. "So women who show off their bodies (mutabarrijah) are women who show off their beauty as they show off (buruj). ${ }^{1}$ Islam as samawi's religion which is paying great attention to women. In addition to teaching the ideal character of a Muslimah who is his image, it's also keeps it from avoiding bad things that can hurt and tarnish her fit rah. In terms of their basic clothes, Islam is known as Agama which highly respects and respects the values of beauty, cleanliness and neatness. Even Islam always encourages followers to always decorate and beautify themselves in a normal and reasonable manner in order to worship and seek the pleasure of Allah. $^{2}$

Beauty from the inside is usually obtained from the education of parents, the environment and also the nature inherited by their parents. Speaking about physical beauty, I slam prohibits women from doing tabarruj (exhibiting jewelry). As for the tabarruj prohibition which Allah SWT has set in Surah al-Nur verse 60. Allah SWT says:
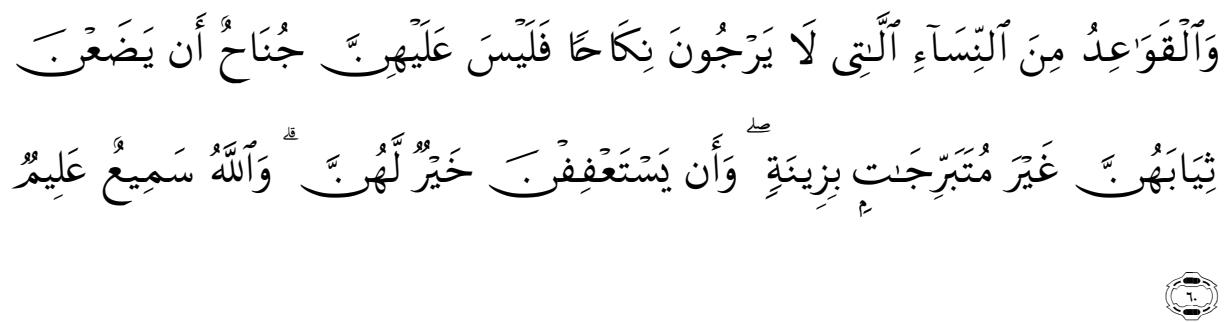

"And women of post-menstrual age who have no desire for marriage - there is no blame upon them for putting aside their outer garments [but] not displaying adornment. But too modestly refrain [from that] is better for them. And Allah is Hearing and Knowing. ${ }^{3}$

\footnotetext{
${ }^{1}$ Ni'mat Shida \& Lutfi Al-Manfaluth, Tabarruj and Hijab , (Tp, Tt), p. 23.

2 Siswati Ummu Ahmad, Dosa-Dosa Yang Digemari Wanita Indonesia, (Solo; Pustaka Arafah, 2014), p. 10

${ }^{3}$ Depag RI, Al-Qur'an Dan Terjemahan, p. 358
} 
Islam protect women with the rule that women are allowed ornate on condition of not changing the nature which create by Allah. As we know that decorated the same as part of the faith, a duty for every Muslim, in dressing or make up a women must be in accordance with the guidance in the A l-Qur 'an and hadith. Because ornate able to characterize and i d entity. Identity means the characteristics or special circumstances of a person or one's identity. Where it has been described in the A l-Qur 'an. Tabarruj for a Muslim woman is forbidden because Allah has clearly banned it. Even including those that must be guarded first in earnest. Proof when Rasul SAW allegiance Ruqaiqah bint Umaimah, he said, "I pledge allegiance to you not to associate with Allah with anything, not to make lies that you do with your hands and feet, not to mourn, and not to be as ambivalent as the ignorant women did. 4

The phenomena that have been carried out by most women in this day and age, by stripping off their clothes, preening, decorating, revealing the jewelry that has been worn, and other behaviors that are nothing more than carrying out other sins without adding to their awareness. And should the people who are truly obedient to Allah SWT. And that means: there is no slander after me which is greater for men than women. "( Muslim). Allah SWT has given favor to mankind by providing a way to get clothes so that they can cover their genitals, as well as jewelry to turn them away. Allah provided the materials from the clothes themselves such as cotton, animal fur, and silk and so on. Allah SWT has also given instinct to find ways to plant these materials and how to make them in various ways such as weaving, spinning and sewing. ${ }^{5}$ Whatever the shape, slander always has a bad impact on the bearer. In this case, Khalid bin Abdurrahman Ash-syayi detailed

\footnotetext{
4 Siswati Ummu Ahmad, Dosa-Dosa Yang Digemari Wanita Indonesia, (Solo; Pustaka Arafah, 2014,), p..10 847

5 Mahmud Syaltut, Tafsir al- Qur'anul Karim, Juz (Bandung: CV Dipenogoro, 1990), p..
} 
the danger of women showing off their genitals, as well as the impact of their slander for men, including the following:

1. Men will dereliction of duty and its obligations due to interference by appearances sexy of the women he sees on the streets, vehicles, markets and so on.

2. The emergence of a desire to commit a planned crime. Because, women who show off their bodies.

3. The breadth of opportunity to direct one's eyes to women.

4. The loss of a man's good name if the one who exhibits his jewelry or body turns out to be his wife or family member. He will get reproach and insults from the community. Worse, if he goes out together, it means he approves the action.

5. Increasing wrath of Allah Almighty. If he directs his eyes to the slander of the woman. ${ }^{6}$

From that Allah gives an opportunity to the Muslims as well as Muslim, young and old, to equally thinking, comparing the laws of Allah that on moral improvement and morals laws of Jahiliyah involving propaganda satan, which se flashback fun but sat it down. 7

\section{The Definition of Tabarruj}

Tabarruj is according to the language of origin of the word from (نبرج) Tabarrajna and Tabarruj were taken from the word ( برج ) baraja that is visible and high. Rule of forbidde for doing tabarruj means forbidding to display "jewelry" "in a general sense that is usually not shown by a good woman, or using something unnatural to use such as dressing up excessively, or walking waddling and so on. ${ }^{8}$ Whereas according to the terminology of Islamic teachings, tabarruj is the display of jewelry, the aurat and the beauty of his body other than to his husband imam Bukhari defines tabarruj by

\footnotetext{
${ }^{6}$ Mundhir Imam Ar-raisyi, Op. Cit., p.. 163.

${ }^{7}$ Ar-raisyi Mundhir Imam, Wanita Dan Harga Diri, (Jombang ; lintas Media 2007), p., 161-162

8 Ni'mat Sdiqy, Pamer Aurat At-Tabarruj, (Kairo:Granada Nadia, 1994), p.. 29
} 
showing the beauty or beauty of a woman's self. ${ }^{9}$ According to Ibn Kathir, Tabarruj is a woman who goes out of the house walking in front of men with the intention of inviting their passions. This is what is called tabarruj jahiliyah. The decorating in Arabic is contained in the meaning of "tabarruj" which according to Imam AlBukhari means the act of a woman who exhibits all her beauty.

Origin of the word "tabarruj" means itself is taken from the word 'al-Buruj' which is building a fort or a high palace. So a woman who is reveals her beauty, as a fortress, a palace or a tower that towers, and of course attracts the attention of those who look at it. According to Sheikh Al-Maududi, the word tabarruj when linked to a woman has three meanings, namely:

1. Appearing the beauty of the face and the parts of the body that arouse lust before men who are not their muhrim.

2. Spread beautiful clothes and jewelry in the presence of men who are not their muhrim.

3. Showing off and walking in front of men who are not their muhrim. ${ }^{10}$

Tabarruj is displaying jewelry and elegance which should be covered because it can invite male lust, the meaning of tabarruj includes the notion of walking around in front of men such as showing hair, and jewelry such as necklaces, gems and etc.

\section{Tabarruj according to Interpreters}

The verses concerning about tabarruj, the researcher more focus on three surah just that, Surah al A'raf 26, an Nur surah 60 and surah Ahzab 33, in the process of interpreting the verses about tabarruj writer will use some the book of commentary, which is where the interpretation of the book made reference is three, namely the interpretation of $\mathrm{Al}$ Misbah, the interpretation of Ibn

\footnotetext{
${ }^{9}$ Hasbi Ash-Shidqy, Tafsir An-Nur, (Jakarta :Bulan Bintang, 1994), p.. 26

10 Muhamad Walid, Etika Berpakaian Bagi Perempuan, (Malang ;UIN -Maliki Press, 2011), p. 79.
} 
Kathir and the interpretation of Al Azhar, the researcher also gets a hadith relating to tabarruj.

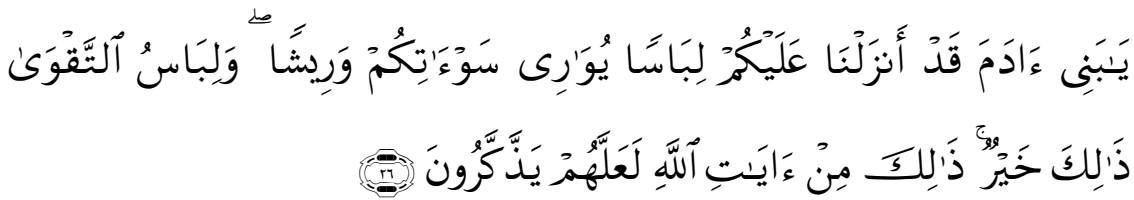

Son of Adam, Verily we have sent down to you clothes to cover your nakedness and beautiful clothes for jewelry. And taqwa clothing. That is the best. that is part of the signs of Allah's power, Hopefully they will always remember. ${ }^{11}$

There are three surahs that explain tabarruj, the surah that descends in Mecca, namely (surah al A'raf) while in Medina (surah an Nur and al Ahzab) the three surahs do not have the reasons for the decline of the verse or asbabun nuzul, because not all surah in the Qur'an has asbabun nuzul, because the verse is a command from Allah which is conveyed through the Qur'an. M. Quraish Shihab explained in his commentary Tafsir al-Misbah that verse 26 advised Adam's son, Adam's son and daughter, from his first to last son of his descendants that indeed the Almighty Allah had lowered / prepared clothing to cover the nakedness and the Inner deficiencies that can be used daily and also prepare feathers as beautiful clothing materials to decorate themselves and used on special occasions. and besides clothing made from materials, Allah SWT also prepared taqwa clothing, the most important and the best clothing. clothing materials that exist on this earth is a gift from the signs of Allah, I hope you will always remember and be grateful for the favors which Allah gave to you. ${ }^{12}$

Tahir Ashur prayed this verse that Allah SWT . Inspire Adam. in order to cover his nakedness. This was later copied by his grandchildren. Humans were all reminded of the pleasure to remind that it was a legacy from Adam. and this will encourage

\footnotetext{
11 Departemen Agama RI, Op. Cit.,p.. 153

12 Quraish Shihab, Tafsir Al-Misbah, Pesan, Kesan dan keserasiaan Al-Qur"an (Jakarta: Lentera Hati, 2004), Juz 5, p.. 56
} 
them to be grateful because this verse uses the word We have decrease to show the benefits of using clothing. ${ }^{13}$ In this verse Quraish Shihab gives an explanation of the meaning of libas namely everything that is used, whether body cover, head, or which is worn on the fingers and arms such as rings, and bracelets. While the word risy in the beginning means fur and because animal fur is a decoration and until now used by some people as decoration both in the head and wrapped around the neck, then from the explanation above it can be understood the meaning of clothing that functions as decoration. From here it can be understood two functions of the many functions of clothing. First, as a cover of body parts that are judged by religion and / or judged by someone or society as bad when seen. Second is as decoration that adds the beauty of the wearer. This gives a signal that religion provides ample opportunities to beautify the state and express beauty.

Rasullah SAW said.

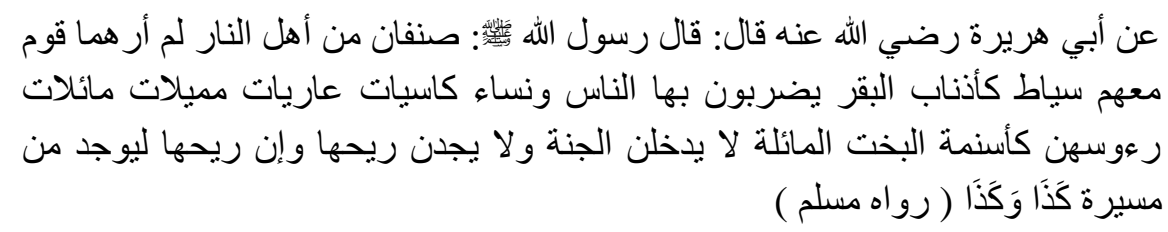

There are two classes of people who are residents of hell, who I have never seen it before; that is, a group of people who have whips like cows that are used to hurt humans; and a woman who opens her aurat and dresses thinly stimulates and waddles her head like a hump of a camel. They cannot enter heaven and smell it. Even though the smell of heaven can be smelled from a distance and so on, (HRMuslim $)^{14}$

His word libas al-taqwa hinted clothes spiritual As described by Rasululah SAW that faith as something that is not dressed and clothing is taqwa. Taqwa clothing if worn by someone then $M a$

\footnotetext{
13 Ibid, p.. 57

14 Muslim bin Hajaj, Șahị al-Muslim, Jilid 2, Cetakan pertama, (Riyadh: Dar alThaibah, 2006), p.. 1021.
} 
'rifat will be the main capital, self-control, characteristic of his activities, longing for the divine mount, and prayer as his favorite eyes. If piety has adorned someone's soul, then his identity will be preserved, again his appearance is graceful. ${ }^{15}$ Taqwa clothing is rohani/soul clothing that covers things that can be embarrassing and worsen the appearance of a human if he is open. Openness of physical and spiritual genitals can cause pain in the human psyche, but the feeling of pain if an open spiritual aura will be more painful than in the openness of good physical genitalia in the world even more in the end. The openness of physical genitals can be tolerated by Allah SWT if there is an urgent need, because the prohibition of opening aurat is intended to prevent humans from falling into something that is forbidden because of His Essence, in other words avoiding humans falling into the openness of spiritual aurat. ${ }^{16}$

This verse can also be understood as showing the fourth function of clothing. Tahir Ibn 'Ashur wrote in his commentary that libas al-taqwa read by Imam Nafi, Ibn Amir, Al-Kisai and Abu Jaf'ar with Nasab (read libasa) instead of libasu as other readings. This nasab reading explains that taqwa clothes are the same as the two previous clothes, namely the same clothes that Allah SWT revealed , if so, of course it is not something abstract, but concrete. Therefore, if read nasab taqwa is meant here is not fearing that the popular religious sense that efforts to carry out the commands of Allah and avoid His prohibitions, but the meaning is the meaning of the language, namely maintenance / protection. From here it can be understood that Libas al-taqwa is clothing that can protect and protect someone. This can be a sign of other functions of clothing, namely maintenance functions. Indeed another verse is found which explains the function of maintenance, namely through His words:

${ }^{15}$ Quraish Shihab, Op. Cit, p.. 57

16 Ibid., p.. 58 


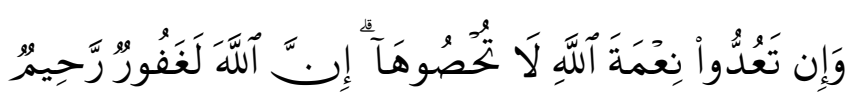

And if you should count the favors of Allah, you could not enumerate them. Indeed, Allah is Forgiving and Merciful. QS AnNahl, 18) ${ }^{17}$

Concluding this paragraph la 'allahum yadh-dhakkarun switch becomes the third person in the previous editorial thing which took the form of the second persona. On the other hand the word yadhdhakkarun at first is yatadhakkarun then the letter ta 'is inserted into the letter dhal so that it is unwritten and unreadable. This is to imply that remembering here is not absolutely must be a perfect form, but only to remember the blessings of Allah SWT by giving thanks. The transfer of the editor from the second person to the third person aims to prevent the impression that might appear in the mind of the person that this guidance and warning is only addressed to Muslims, at things are actually addressed to all parties. Thus more or less the description of Biqa' $i$.

According to Ibn Kathir, Libaa san yuwaa ri sau'aatikum : common clothes, must cover the genitals. Wa rii sya : and jewelry, equipment of perfection or excess. also means: beauty, or something new. One day Abu Umaya wore new clothes, and when he had used it he read: allhamdu lillahil Ladzi kasaana this is the bihi aurati wa atajammalu bihi fi hayaa ti (all praise be to Allah SWT who gave clothes to cover my nakedness and be decorated in my life) . Then he said. I have heard Umar Bin Al-Khatab ra, said that the Messenger of Allāh. Said.

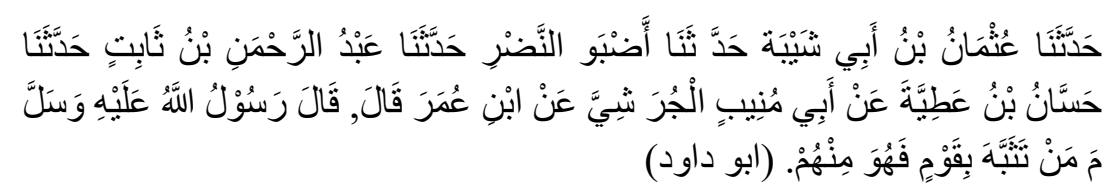

Has told us Usman bin S-yaibah, has told us Abu an-N adhri, told us Hasan bin'Atyah from Abi Munib al Jurasiy from U mar said,

17 Departemen Agama RI, Op. Cit., p.. 269 
the apostle ul was saying whoever resembles a people then he is like them. 18

The hadith clearly states that women at the time of the Prophet when going to the mosque to perform prayers with the Prophet, they closed their genitals. This is to minimize lust that flares up for those who see it, because the vital organs in a woman are tightly closed. ${ }^{19}$ There is a mawaddatan and rahmatan, namely love and affection. Become a respectable housewife. Here, especially the wives of N Abi who are the mothers of believers. Because of women jahiliyah the past if they are decorated, is so that it looks prettier, more stretched, decorated to make it more attractive to people's eyes. Decorate to make it look plumper . Decorate so that his eyes glare. Doing make up excessive is like calling out to be held. ${ }^{20}$ And if the teaching of Prophet has been received, the priest has been lodged in the chest doing make up excessive but Islam, let the women doing make up are not conspicuous.

It is not explained in this verse what is the "fashion " of clothing. Or what forms of women's clothing should be worn, the Arabs or the Persians? this is a guideline to be used in each period and in each of the four public I slams. It is not discussed whether women's clothing stands according to the Arab model in the Prophet's era, or European model skirts or clothes in Minang, Malay kebaya, or Javanese kebaya. The point is " do not decorate with ignorance ", instead, take it according to the courtesy line I slam. So it is not surprising if at the connection of the verse: ${ }^{21}$ "And establish your prayer and give zakat and obey Allah and His Apostles "

18 Sulaiman Abu Daud bin al-Asy"ats as-Sijistani, Sunan Abi Daud, (Beirut: Dar AlKutub al-Ilmiah, 1964) 48.

${ }^{19}$ Nashruddin Baidan, Metodologi Penafsiran al-Qur'an (Yogyakarta: Pustaka Pelajar (1998), p.. 31

${ }^{20}$ Hamka,op cit., p.. 196

${ }^{21}$ Ibid, p. 197 
It cause of execute of prayer, zakat and any commands of Allah and Rasul that stop the banned would be enormous influence on the clothes and how to make up. Then the connection to the verse that explains what is the reason for the matter of clothing is warned by God, that is : No one that Allah need to do, is only clean your body from anythig that in your body (end of verse 33). So the conclusion of the surah al araf verse 26 Allah loves beauty as is the matter of piety according to the Sharia which is used by Muslim women because it is a form of obedience of a woman to Allah SWT.

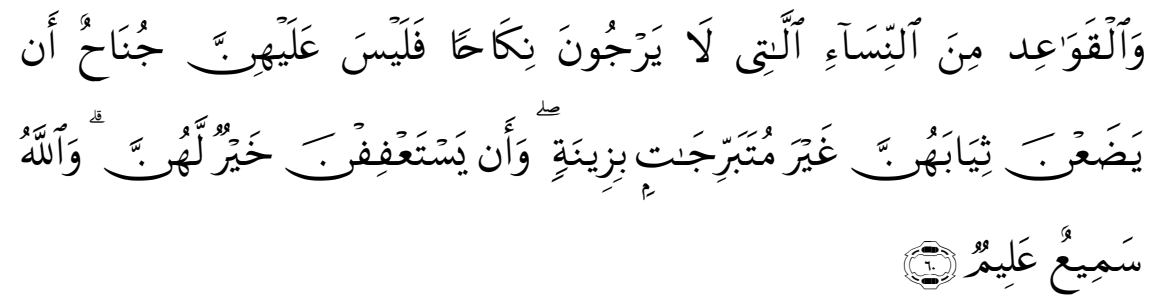

and old women who have been stopped (from menstruation and conceived) who do not want to marry (again), it is not for them to take off their clothes by not (intending to) reveal jewelry, and Validation is better for them. and God is Hearer, Wise.22

According to M. Quraish shihab al qawa'id word is the plural form of the word qa'id pointing to an older woman. The word was originally used in the sense of sitting. An old woman is called qa'id because she sits at home, doesn't have to walk anymore, or falls because she can't give birth due to aging. A Word of his llah allati la yarju na's wedding (ladies who had no desire to again marry, not the additional requirement of aging, but it was the explanation about the natural phenomeon that usually attached to the old woman. ${ }^{23}$ What is meant by the word ats-siyah here is the most of their clothes, or clothes that cover to cover part of your body or aurat. This permit is not only due to the fact that the elderly woman has experienced severe pain in wearing various clothes, but more because seeing her does not lag causing arousal stimulation.The

22 Departemen Agama RI, Op. Cit., p.. 358

23 Ibid, p.. 398 
word mutabbarijat is taken by the word tabarruj, which is openness. The prohibition on tabarruj here means the prohibition of displaying "jewelry" in its general sense which is usually not seen by good women, or using something that is not natural used. Like make up excessively, or walk with a swing and some. Appearing something that is usually not displayed, except to the husband can cause stimulation or cause interference from nosy. This verse ban is on old women, so of course the young are more forbidden. In this context the habitual of woman, has a very large effect in setting boundaries and is not acceptable. This can be seen in a hadith:

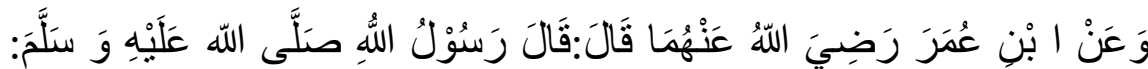

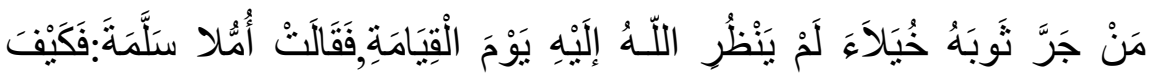

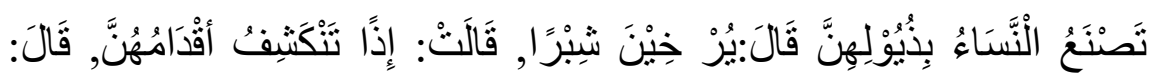

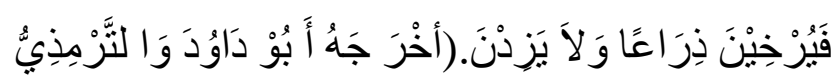

from Ibn Umar Allah be upon him Anhuma said, Rasullah SAW said, "Whoever drags his clothes with the intention of boasting, then Allah SWT will not look at him at the end of the day," Um Salamah said, "then how should a woman with a hem of cloth (under the ankle). "He said, Salamah," then (still able) to see the soles of their feet "then answer," if so, then they may extend a cubit (along the fingertips to my knees) and not add more. "(HR. Abu Dawud and At-Tirmidhi). ${ }^{24}$

There is also a ban on - ta $b$ understands it in the sense arruj curfew with the revealing clothes without hoods and se kinds. Whereas if it is inside the house, this is permissible, even though there are other than mahram who see it. ${ }^{25}$ According to Ibn Kathir Three of the above teaches the rules of association in the household, that slaves are male. And women who have maids at

24 HR. At-Tirmidzi, p. 1731

25 Ibid, p.. 398-399 
home likewise be children who reach the age of puberty, should ask permission if they are about to enter the adult bedroom, especially at times when the body is usually open a lot, that is before dawn prayer. midday and after before dawn prayer. At the time of the day and after the evening prayer at the other three times people usually sleep in rooms alone or with their wives. no why do people enter without permission. And children from those who are not criminals who have returned, should ask permission first if you will enter, according to the way the people mentioned in paragraphs 27 and 28 of this letter are required to ask permission. And old women who have stopped menstruating and have exceeded their reproductive period and do not want to remarry not why they left their outer clothes, which when opened are not showing the aurat, with no intention to reveal and make much of her jewelry.

Whereas according to Buya Hamka, then in verse 60 it is explained again about women who are not expected to get married again, which is called Qawa'id, women who have sat down, no longer menstruate, meaning there is no more sexual attraction (sex ) because it has been extinguished c ah a yes. Do not be tempted again lust man looked at her and she was not dressed an $n$ complete, meaning that no matter if in pull his outer garment to cover his body.

Half of the scholars said that the whole body of the genitalia, which means that the whole is $d$ a yes attraction. Therefore, let him dress, which can cover the lust of those who look at him, which means polite. There is outerwear and there is underwear to wear at home. ${ }^{26}$ Generally women I slam in Indonesia if they come out wearing a headscarf. Do not as a western clothing now, which every aspect of the cutout was deliberately intended to cause lust, then the woman who was getting old, did not menstruate. Again, not in the clothes of her outer clothes around her house that it was not, as long as her glory as a parent $\mathrm{d}$ i respect remain at his watch.

${ }^{26}$ Hamka, Tafsir Al Azhar, Penerbit Pustaka Panjimas, p.. 226 
The conclusions of the surah Nur is a women who have been menopausal are allowed for them to go out of the house decorated with but not decorated too much and according to the Sharia and also dress modestly who do not show their jewelry.

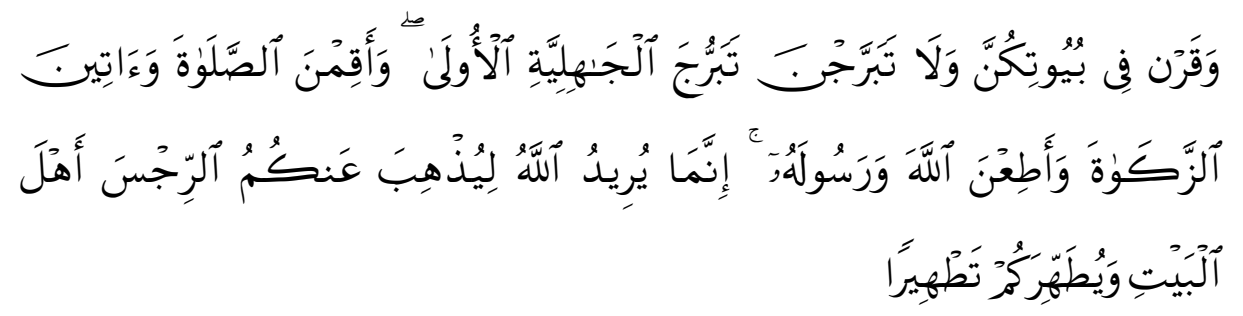

and you should remain in your house and do not decorate and behave like the Jahiliyahs that were before and establish prayer, give alms and obey Allah and His Messenger. Verily, Allah intends to eliminate sin from you, $O$ Lord, and cleanse you as clean as possible. ${ }^{27}$

According to M, Qurais Shihab after the last verse gave the wives of the Prophet SAW . concerning speech, now continued with guidance regarding actions and behavior. Allah SWT said: and besides he remained you stayed in your house except if there was a need to come out which can be justified by norm or religion and give great attention to your household and not to collide with you that is decorated and behave like tabarruj jahiliyah ago and carry $\mathrm{l}$ $\mathrm{a} \mathrm{h}$ is continuous and properly prayers, which is either mandatory or the sunna. Said qarna read by a ' shim and Abu Fa'far drawn from said iqrarna in the sense stay and Draw at a steady basis. there are also those who argue that the word is taken from the word qurrat'ain and this means something that is pleasing to the heart. ${ }^{28}$

The tabarrajna and tabarruj words are taken from the words baraja, namely show/ open and high, from here they are understood also in the sense of clarity and openness because that is the state of things that appear and are high. the prohibition on

\footnotetext{
27 AL-Jumatul Ali, Al-Qur'an dan Terjemahan, (Jakarta :Cv. J-ART, 2005), p.. 423

${ }^{28}$ Quraish Shihab, Tafsir Al-Misbah, Pesan, Kesan dan keserasiaan Al-Qur"an (Jakarta: Lentera Hati, 2004), Juz 5, p.. 263
} 
tabarruj means the prohibition of displaying "jewelry" in a general sense that is usually not displayed by a good woman, or uses something that is not natural to use. Like dressing up excessively, or walking with strings and so on. Appearing something that is usually not seen except to the husband can invite another man's admiration which in turn can cause stimulation or result in nosy interference. Refer to Qs, An Nur: 60 The word al jahiliyah is taken from the word ignorant which is used by the Qur'an to describe a condition in which the people ignore the values of divine teachings, do things that are not fair, both for encouragement of lust, temporary interests, and shortsightedness. Therefore this term stands alone do not show before Islam, but shows a period in which the characteristics of society are contrary to the teachings of Islam, anytime and anywhere.

The verse above stated that men who have bad character with al-ula . Namely the past. Various interpretations of the past. Some point to the time of Noah As, or before Prophet Ibrahim As. It seems that more can be said is the period of Prophet Ibrahim As, presumably the more appropriate is to declare the period before the coming of Islam under the Prophet Muhammad divine. On the other hand, the existence of what is called "past ignorance", implies the existence of "later ignorance". ${ }^{29}$

As for the word ar'rijs at first it means dirt. This can cover four things. Defilement based on religion's view, or reason, or human nature, or these three things. Khamar/wine and gambling are dirt in the view of religion and reason. Khamar/wine which is attached to the body is dirt from the aspect of syari ', drinking it is dirt in the view of Religion and reason. Dust in clothes and sweat that is attached is dirt in the view of human nature. While the carcass is dirt in the view of religion, reason and also human nature. The word al baits literally means home. What is meant here is the house where the wives of the Prophet Muhammad SAW lived. He built

${ }^{29}$ Ibid, p.. 264 
the house side by side or together with the mosque. It consists of nine very simple rooms.

As for the word ar'rijs at first it means dirt. This can cover four things. Defilement based on religion's view, or reason, or human nature, or these three things. Khamar/wine and gambling are dirt in the view of religion and reason. Khamar/wine which is attached to the body is dirt from the aspect of syarii ', drinking it is dirt in the view of Religion and reason. Dust in clothes and sweat that is attached is dirt in the view of human nature. While the carcass is dirt in the view of religion, reason and also human nature. The word al baits literally means home. What is meant here is the house where the wives of the Prophet Muhammad SAW lived. He built the house side by side or together with the mosque. It consists of nine very simple rooms.

The islamic scholars' opinions differ on who is covered by the verses in this verse. Seeing the context of the verse, the wives of the Prophet Muhammad. Included in it, even those who were first addressed by the context of this verse. While another scholar expands by understanding the word al-bait in the sense of baitulah al-haram so that ahl-bait is a mekah resident who preaches. But this opinion is clearly out of the context of the verse. But from the other side, it cannot also be said that the ahl-bait is only the wife of the Prophet's wife.

This means that ahl bait is not only the wives of the Prophet but also includes many men. This view is supported by a history stating that this verse came down at the house of the Prophet's wife. Ummu Salamah. At that time the Prophet SAW. Calling Fatimah, daughter (grandson of the Prophet SAW). Namely Al Hasan and Al Husain. The Prophet SAW covered them with a veil while praying: 'their God, they are the ones who are my temple, cleanse them their sins and purify them as holy as they are'. Ummu Salamah who saw this incident said: I want to join the veil, but the Prophet. Prevent 
me while saying: you are in virtue ... you are in . "(Narrated by AthThabran and Ibn Kathir through Ummu Salamah Ra.).

Presumably the Prophet SAW. Refusing to put Ummu Salamah into the veil, not because he was not the master of the temple, but because the one who entered the veil was what the Prophet prayed for. Literally special, while Umm Salamah has been included from the beginning in the Ahl Bait, through the context of this verse. On this basis the salaf scholars argued that ahl bait was the entire wife of the Prophet SAW. With Fatima, "Ali Ibn Abi Talib and Al Hasan and Al Husain. The famous Shia cleric, Tabataba'i limited the understanding of the verse in this verse to only limited to five people who were included in the veil, namely the Prophet Muhammad, Ali Ibn Abi Talib, Fatima Az Zahra 'and Al Hasan and Al Husain. Their cleansing of their sins and purification is understood in the sense of ' isbmat 'that is their maintenance from sinful acts. 30

Imam Malik and Abu Hanifah argued that and Abu Hanifah argued that ahl bait was all members of the family of Muhammad. The one with the line of love arrived at Hashim, the grandfather of the Prophet Muhammad. Abdullah's son, son of Abdul Muthalib, son of Hasyim. Al Qurthubi asserted that Religion is fulfilled by the guideline so that women stay at home, and do not leave the house if there is no need to be justified by Religion such as prayer.

Thahir Ibn'Asyur underlined that the command of this verse was addressed to the wives of the Prophet as an obligation, whereas for Muslim women besides their nature it was perfection. That is not compulsory, but very good and makes the woman who heats her more perfect, which is the word of Rasulullah SAW.

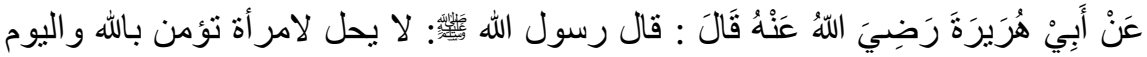

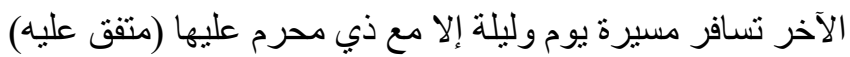

From Abu Hurairah Radhiyallahu Anhu, he said, "Rasulullah SAW once said," it is not lawful for a woman who has faith in Allah and 
the Hereafter to travel as far as traveling one day and one night except with her mahram. ${ }^{31}$

The problem is within the limits of what permits such as allowing them to work "Muhammad Al Qurthubi, one of the Muslim Brotherhood thinkers wrote, in his book ma'rakah at taqilid, that:" the verse prohibits women from working ". It's just that Islam is not happy and does not encourage it. Islam justifies them working as an emergency and does not make it a basis. " In the book Syubuhat haula al I slam, Muhammad Qutub explained that: women at the beginning of the Islamic era also worked, when conditions required them to work, the problem was that jobs were very necessary, needed by the community, or basic needs of certain women. For example, the need to work because no one pays for his life, or because the one who bears his life is unable to meet his needs. ${ }^{32}$

Whereas according to Ibn Kathir the verses above contain the guidance of Allah SWT to the wife, how should they behave and behave in their daily lives as the wives of Rasullah which have the title " ummuhatul mukminin" (mothers of believers) who deserves to be a role model for believing women. Allah Almighty says that if you truly fear Allah, you shall always pronounce good words and occasionally do not speak in a manner that raises the courage of people are acting is not good to $\mathrm{k}$ a mu. Mainly or an unscrupulous who have the intention doing an affair with the woman and you have to stay in your house and do not come out house except for something urgent " Allah says," do not behave, dressed and decorated your jewelry and stimulating manner as those men did in those days jahiliyah. Then Allah commanded rasul wives. So that they will continue to establish prayers, pay zakat and wait for Rasul.

After that Allah said as a lead ofer for them "Allah want to remove the sin from you ". But there are opinions besides the wives

\footnotetext{
31 Shahih Al-Bukhari No. 108, p.,. 354

32 Ibid, p.. 266
} 
of the prophet, including in the words ahlul bait, the daughter of Rasullah Siti Fatimah and her two grandchildren, Hasan and Husen, the second opinion is appointed by several hadiths, which include what was narrated from Anas bin Malik who told the Prophet Muhammad for 6 months every morning at dawn when he passes in front of the door of Siti Fatimah to scatter . pray, $O$ ahlul couplet, verily God will remove sin from you, $O$ ahlul bait and cleanse it as clean as it is . " Also narrated by imam Ahmad Watsilah bin Al-asqa ra anhu. The one who told me "one day I came to the place of Siti Fatimah Ra. Wanting to meet Ali, her husband, who at that time was in the place of Rasulullah SAW. Then Allah said "remember Allah's favor which was especially for you, $\mathrm{O}$ wives of the apostles, that Allah's revelation was revealed at your house as a privilege that was not given to other people. Then practice what is read in your house from the verses and the sunnah.

And according to Buya Hamka, each male feels passion for women. But there are those who hold her politely as controlled by his faith and there is $\mathrm{p} \mathrm{u}$ la the weak control of his mind; That person who has Sexually arousing pressure, people who are "diseased" should not be disturbed. Esspecialy prophet's wive who is a mother of believers. "And settle in your house." ( Base of verse 33). They also looked at her house, which was her husband's house, that was about her peaceful and secure stay. There is a mawaddatan and rahmatan, namely love and affection. To be a respectable housewife. " And do you not decorate in decorated people the ignorant of the past".

Because the ignorant women of the past, if they were decorated, were to appear prettier, more prominent, and to be more attractive to the eyes of people. Be careful as you want to stay in held. So if the teachings of our prophet already get it, faith has been retired $n$ g in the chest do not be excessive. ${ }^{33}$ Prophet Muhammad SAW said.

33 Ibid, p.. 24 


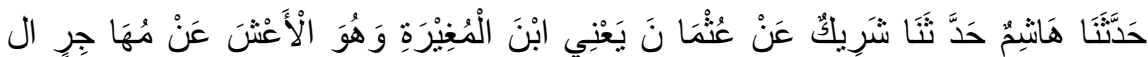

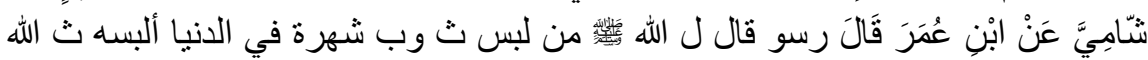

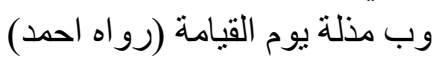

Has told us Hasyim has told us Sharik of 'Uthman namely Ibn Mughirah he is al A' syah from the ash-Syami Muhajir of Ibn Umar, said: The Messenger of Allah said: "whoever wears his great clothes is famous in the world. God wears for him the Day of Judgment contempt (HR Ahmad). ${ }^{34}$

It is not explained in this verse what "fashion" clothing is. Or what form of national women's clothing should be used, the Arabs or the Persians, this is a guideline to be used in each period and in each place in the Islamic community. It is not discussed whether women's clothing is not according to the Arabic model of the era of prophet muhammad, or European model skirts or baju kurung in wast sumatera, Malay kebaya, or kebaya in java. The point is " do not decorate with ignorance ", but be according to the Islamic courtesy. So do not be surprised if the verse connection is called. And make you pray and give alms and obey Allah SWT and his apostles.

"Because praying, zakat and obedience carry out every order of Allah and His Apostles and stop what is forbidden, it is very great influence on clothes and how to decorate.

Then the verse connection explains why, until the matter of clothing is warned by God. That is; "There is no other thing that $A$ will desires is only to remove the defilement from you, O Ahlul bait, and to cleanse you completely clean." (End of verse 33).

Then all the messages of Allah to be conveyed by the Prophet Muhammad to his wives became a guide for every woman who believed who was not the wife of the Apostle. Because there is no other purpose of God is to form an Islamic household, a safe and 
peaceful household, patronized by obedience, clean than a trapped temperament or bad heart disease. And a Muslim household should be filled with the mood of the Qur'an. We too, how great the struggle in this age of modern ignorance is to look at divine truth. But the vile remains vile even though many are swept under the current._ ${ }^{35}$ Surah al Ahzab verse 33 conclusions married women are not allowed to over-decorate and behave like ignorant people and they are better off staying at home not but women out of the house are forbidden but the woman avoids evil things and avoids slander.

Basically, Islam has prohibited women from doing tabarruj (displaying jewelry). In other words, tabarruj is another law that is different from the law of covering the genitals and laws of women wearing veils and headscarves. Even though a woman has covered her genitals and dressed in Muslim syar'i, it does not rule out the possibility of her doing tabarruj.

The prohibition of Tabarruj has been established by Allah SWT Surah al-Nur verse 60. Allah SWT says:

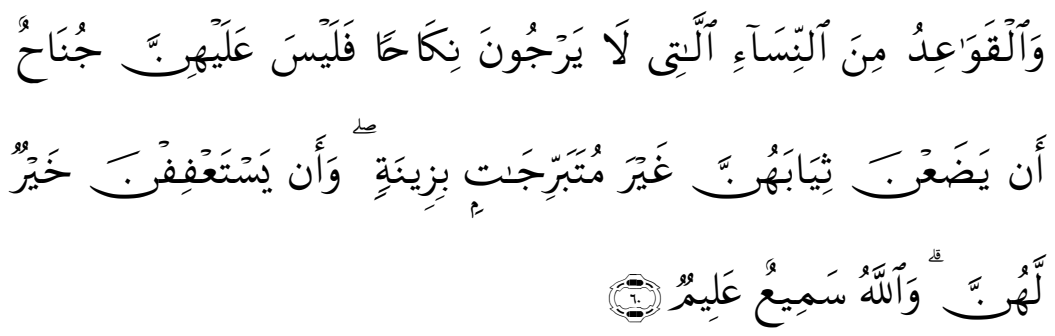

and old women who have been stopped (from menstruation and conceived) who do not want to marry (again), there is no sin for them to take off their clothes by not (intending) to reveal jewelry, ${ }^{36}$ _ and Being polite is better for them. and God is Hearer, Wise. ${ }^{37}$

Understanding muwaqah this verse is, if the old women who have monopose only are prohibited from doing tabarru $j$,

\footnotetext{
35 Kementrian Agama, Al-quran Dan Terjemahan, (Jakarta:Intra Abadi, 2010), jilid VI

36 Kementrian Agama, Al-quran Dan Terjemahan, (Jakarta:Intra Abadi, 2010), jilid VI

37 Kementrian Agama, Al-quran Dan terjemahan, (Jakarta :, Lntra Abadi, 2010), jilid VI
} 
moreover women who young and still have the desire to get married. Reveal the nakedness can be one form of tabarruj, but understanding tabarruj not an indulgence in private parts, but i this case is showing your beauty to attract sympathetic from men, then, tabarruj can be done by a woman who has cover their aurat, and wearing the hijab and khimar which does not cover skin color and body shape.

Tabarruj can occur if women wear hijabs and khimar that are so beautiful with various knick-knacks so that they flirt with their eyes, or make up their faces so prominently by using perfume that is so fragrant that it smells by anyone they pass. A Muslim woman should know that tabarruj is a feature of ignorance and retardation. If a woman is decorated by someone other than her husband, then A will burn it with hell fire because it is not for her husband, if a woman does this it means she has done damage and betrayed her husband.

Islam is actually not anti-face beauty. Beautiful, white and smooth faces are a must. But all the beauty is only for the husband and not for display on the streets so that other men can enjoy it. Women who preen for her husband, which when her husband was at home, he beautify them to dress up and wear a nice and interesting to please her husband and did not preen when her husband was not at home is a picture wan i ta shalihah commendable and glorified. A woman like this can certainly maintain her pride and honor when her husband is not home. So even the household, God willing, will be lasting and harmonious.

Islam also upholds the degree and degree of women. That's why women are told to just stay at home. So that his respect is maintained from the disturbance of other men who see and are attracted to him. Women who are shalat don't need to be afraid their worship will be hindered or their reward is lacking, if they remain silent at home, because women who serve husbands with 
sincerity, the reward is equated with men who fight to defend the praise of Islam. As stated by Rasullah SAW.

Who among you (the wives and mothers) sincerely lives at home to take care of children and serve all the affairs of her husband, if he will get a reward whose levels are the same as the reward of the mujahidin in the way of Allah . (HR. Bukhari and Muslim).

Muslim women must be able to take care of their faces for the happiness of their husbands. Very human if the husband wants his wife to be beautiful. Beauty can evoke a sense of belonging, a sense of longing and evoke biological desire. Having a wife who can take care of her face will be her own happiness and pride. ${ }^{38}$

Reveal the nakedness can be one form of tabarruj, but understanding the tabs a rruj not an indulgence in private parts, but showing the beauty to attract men, then, act $\mathrm{n}$ y a tabarruj can be done by a woman who had been close their aurat, and wearing headscarves and khimar that do not cover well the skin color and body shape. Tabarruj can occur if women wear hijabs and khimar that are so beautiful with various knick-knacks so that they flirt with their eyes, or make up their faces so prominently by using perfume that is so fragrant that it smells by anyone they pass.

A Muslim woman should know that tabarruj is a feature of ignorance and retardation. If a woman decorated in meaning other than her husband, then Allah will burn in the fire of hell because doing make up not to her husband, if a woman does this mean he has done damage and betrayed husband.

\section{Conclusion}

From Al-maraghi's interpretation of the verse on social ethics in the letter Al-hujurat verses 10-13, namely: explains that the real Muslim is another Muslim brother who does not abuse each other, does not blur each other, does not reproach each other and does

38 Ar-raisyi Mundhir Op cit, p.. 155 
not extend each other's problems, Surah Al- the verse 11 verses explain ridicule other people, and women who are mocked may be better than those who make fun of them, so they are better than dowry. Don't you call on others with evil and with hatred, and don't call it a bad name. Verily Allah is the Forgiving to His people who repent and whoever does not want to repent, they get a punishment Allah. Al-Hujurat verse 12 Don't prejudice other people in fact some of that prejudice is a big sin and don't you also visit some of the others in fact one of you likes to eat his brother's flesh after his death. Surely Allah accepts for those who want to repent and Surah Al-Hujurat verse 13 in fact we will take you along with Adam and Eve, among some of you make fun of some of the others and distance each other in fact you are brothers

According to M. Quraish Shihab letter Al-hujurat verse 100 believers of peace, even though the conflict only occurs between your two brothers and fear Allah, so that you will get the mercy of unity and unity, surah Al-hujurat verse 11 and women who make fun of other women may be those who are mocked better than those who are ridiculed and do not mock anyone secretly with words, deeds or gestures because it will overtake themselves. And is evil with bad titles, as bad as evil is the call of wickedness, that is the bad call of the faithful, Surah Al-Hujurat verse 12 don't you find fault with someone else and talk about the shame of others. Because it is the same as eating his brother who passed away, in fact Allah is the most giver of repentance again Most merciful and the letter Al-Hujurat verse $13 \mathrm{God}$ created humans from a man and woman namely Adam and Eve or from sperm and ovum and make you nations, tribes so that you know each other and help each other - help and complement each other. Indeed, the most noble among you is beside Allah the most fearful among you. so you know each other and help each other - help and complement each other. Indeed, the most noble among you is beside Allah the most fearful among you. tribes so you know each other and help each other - 
help and complement each other. Indeed, the most noble among you is beside Allah the most fearful among you.

According to Ibn Kathir, urat Al-Hujurat verse 10, the believers are brothers, so peace between your two brothers who are at odds, fight or fight. Fear God that you may grasp his mercy, the vein of AlHujurat verse 11 let you make fun of one of your people, insult and despise the other, because those who are despised and molested are better than those who mock, and also don't you call with a bad title that is not liked by those who are called. He who does not repent, he is one of the wrongdoers, surat Al-Hujurat verse 12 you have to far away, because actually steps are the words of the most lies, spying on each other, stealing each other's information, competing with each other, mutual love, hate each other and back to back and urat Al-Hujurat verse 13 Allah created humans from a man and a woman, then make people split, nation, from nation to tribe, so that they know each other. Surely humans are the same in the eyes of God and the most noble is the most fearful person.

The meaning contained in the letter Al-Hujurat verses 10-13 regarding the ethics of association can be seen based on the discussion of the commentators who have explained earlier that the letter al-Hujurat verses 10-13 explain the suggestion to always reconcile among fellow people, the importance brotherhood, the prohibition of making fun of others, demeaning others, gossiping, and the importance that distinguishes between Muslims is only piety. The social ethics values contained in the letter al-Hujurat verses 10-13 are fairness, brotherhood, respect for others, harmonious attitudes, prohibitions on gossiping and taqwa.

\section{Bibliorgaphy}

Saichimurata, Too of Islam, Bandung: Mizan. 2005.

Alfarmawi, Abdul Hayy, Metode Tafsir Maudhu'i Bandung; Cv Pustaka Setia, 2002.

Ali, AL-Jumatul, Al-Qur'an dan Terjemahan.Jakarta :Cv. J-ART, 2005. 
Al-Qashir, Fada Abdur Razak, Wanita Muslimah. Jogyakarta: Darussalam offset, 2004.

As-Sijistani, Sulaiman Abu Daud bin al-Asy"ats, Sunan Abi Daud. Beirut: Dar al-Kutub al-Ilmiah, 1964.

Ass Su'udiyah, Syirkatuth Thaba'ah Al Arabiyah, At Tabarruj Wal Hijab fi Dhou'il Kitab was Sunnah. Jakarta; Granada Nadia T.t.

Ahnan, Mahftuh, Risalah fiqih Wanita. Terbit, Terang Surahbaya.

Alma'ie, Zahrah Ahmad Al, Wahai Putriku Tutuplah Auratmu. Jakarta: Granada Nadia, 1994.

Ahmad, Siswati Ummu, Dosa-Dosa Yang Digemari Wanita Indonesia. Solo; Pustaka Arafah, 2014.

Ar-raisyi, Mundhir Imam, Wanita Dan Harga Diri, (Jombang ; lintas Media 2007),

Baidan, Nashruddin, Metodologi Penafsiran al-Qur'an (Yogyakarta: Pustaka Pelajar 1998.

Dâwûd, Abû. Sunan Abî Dâwûd. Riyad; Bait al-Afkar ad-Dauliyah, t.t.

Departemen Agama RI, Al-Qur'an Dan Terjemahannya. Bandung: Gema Risalah Press,1992.

Hanbal, Ahmad Bin. Musnad Ahmad. Riyad; Bait Al-Afkar Ad-Dauliyah, t.t.

Husnul Albab MZ, Wanita Yang Dicintai dan di Benci Allah Swt. Surahbaya :Bintang Uaha Jaya, 2011.

Hajaj, Muslim bin, Șahị al-Muslim, Jilid 2, Cetakan pertama. Riyadh: Dar al-Thaibah, 2006.

Jundi, Anwar, Gelombang Tantangan Muslimah, Cet kelima. penerbit CV. Pustaka Mantiq.

Kementrian agama, Al-quran Dan Terjemahan. Jakarta:Intra Abadi, 2010. 
Manan, Imran Mu'amal Haidy A., Terjemah Tafsir ayat Ahkam Ash Shabuni. Surahbaya :Bina Ilmu, 1990.

Muhammad, Su'aib, Tafsir Tematik, Cet, 1:2013. Penerbit UIN Maulana Malik Malang.

Syuqqah, Abdul Halim Abu, Kebebasan Wanita: Jilid ke Empat. Jakarta: Gema Insani

Shidqy Hasbi Ash-, Tafsir An-Nur. Jakarta :Bulan Bintang, 1994.

Shahab, Husein, Jilbab Menurut Al-Qur'an dan As-sunah. Bandung: Mizan, 1994.

Syaltut,Mahmud Tafsir al- Qur'anul Karim, Juz Bandung: CV Dipenogoro, 1990.

Sdiqy, Ni'mat, Pamer Aurat At-Tabarruj. Kairo:Granada Nadia, 1994.

Shihab, Quraish, Tafsir Al-Misbah, Pesan, Kesan dan keserasiaan AlQur"an. Jakarta: Lentera Hati, 2004.

Syafe'i, Racmat, Ma, Pengantar Ilmu Tafsir. Bandung : Pustaka.

Siti Fatimah'Abdilah, Buku Pintar Ibadah. Jakarta Timur : Jalamitra Media.2013.

Umar, Ansori, Fiqih Wamita. Semarang; Vc Asy-Syifa;1986.

Walid,Muhamad, Etika Berpakaian Bagi Perempuan. Malang ;UIN -Maliki Press, 2011. 
190 | AJIS, Vol. 3 No. 2, Dec 2018 